\title{
IDŐJÁRÁS
}

Quarterly Journal of the Hungarian Meteorological Service

Vol. 123, No. 3, July-September, 2019, pp. 391-408

\section{Anomalies in the length of the growing season in Poland in the period 1966-2015}

\author{
Katarzyna Szyga-Pluta* and Arkadiusz M. Tomczyk \\ Department of Climatology \\ Institute of Physical Geography and Environmental Planning \\ Adam Mickiewicz University in Poznań \\ Krygowskiego 10, 61-680 Poznań, Poland \\ *Corresponding author E-mail: pluta@amu.edu.pl \\ (Manuscript received in final form July 17, 2018)
}

\begin{abstract}
The purpose of the study was to determine the anomalous length of growing seasons, the frequency of their occurrence, and to determine the temporal and spatial changes of their frequency in Poland in the period 1966-2015. The analyses used daily average air temperature values for 30 stations located in Poland from years 1966-2015 (Fig. 1). The data was provided by the Institute of Meteorology and Water Management National Research Institute. The growing season was defined as the period with average daily air temperature $\geq 5^{\circ} \mathrm{C}$. The start and end dates of the growing season were determined using the mathematical formulas proposed by R. Guminski (1948). In the period 1966-2015 in Poland, anomalously short growing seasons occurred sporadically and covered the largest area of Poland in 1997. Short growing seasons were more frequent in the first three decades of the analyzed multi-year period, and long growing seasons were characterized by higher frequency in the second half of the surveyed period. Anomalously long growing seasons before 1990 occurred sporadically and only in individual stations. Anomalously short growing seasons occurred only in the middle eastern part of Poland, while anomalously long ones covered most of the country.
\end{abstract}

Key words: growing season, typical and anomalous length, climate change, Poland 


\section{Introduction}

In the Northern Hemisphere, the 1983-2012 period was probably the warmest 30-year-long period in the last 1400 years (IPCC, 2013). In most surface temperature data sets, the years 2014, 2015, and again 2016 set new global heat records since the start of regular measurements (Rahmstorf at al. 2017). According to the NOAA (2018), in the period 1880-2017, 9 out of 10 warmest years are those after 2000, and the warmest year was 2016. The forecast increase in the growing season length is a consequence of the increase in the average global air temperature observed in recent years. Nieróbca et al., (2013) indicated that in the perspective of 2030, the growing season in central Poland may increase by 10-14 days in comparison to the reference period of 1971-2000, and in the perspective of 2050 by 18-27 days, while in south-western Poland, respectively, by 11-17 days and 22-30 days. Also in the long term, a longer growing season in Poland can be expected, which will be a consequence of the increasing air temperature, even by $3.8^{\circ} \mathrm{C}$ in 2071-2100 (Piniewski et al., 2017). A similar trend is forecasted by Skaugen and Tveito (2004) for Norway in the perspective of 2050. This affects the modification of phenological phases of individual plants (Menzel and Fabian, 1999; Chmielewski and Rötzer, 2001; Chmielewski et al., 2004).

Changes in thermal conditions may also have adverse effects on agriculture (Nieróbca, 2009), causing a decrease in the productivity of some crops, the development of thermophilic weeds, pests, or the emergence of new plant diseases. Changes in the start and end dates as well as the length of the growing season, in addition to the consequences for ecosystems, may lead to long-term changes in the carbon dioxide cycle, and changes in vegetation will affect the climate system (Linderholm, 2006). Changes of different meteorological elements in recent decades have exceeded the limits of the typical cyclical nature of weather conditions, manifested by the intensification of extreme phenomena (Miętus, 2005; Christidis et al., 2007; Tomczyk and Bednorz, 2016; Czernecki and Miętus, 2017; Wibig, 2018).

The subject of the research was the anomalous growing seasons in Poland. The purpose of the study was to determine the anomalous length of growing seasons, the frequency of their occurrence, and to determine the temporal and spatial changes of their frequency in Poland in 1966-2015.

\section{Data and methods}

The analyses used daily average air temperature values for 30 stations located in Poland, excluding the mountain regions, from years 1966-2015 (Fig. 1). The data was provided by the Institute of Meteorology and Water Management National Research Institute. 


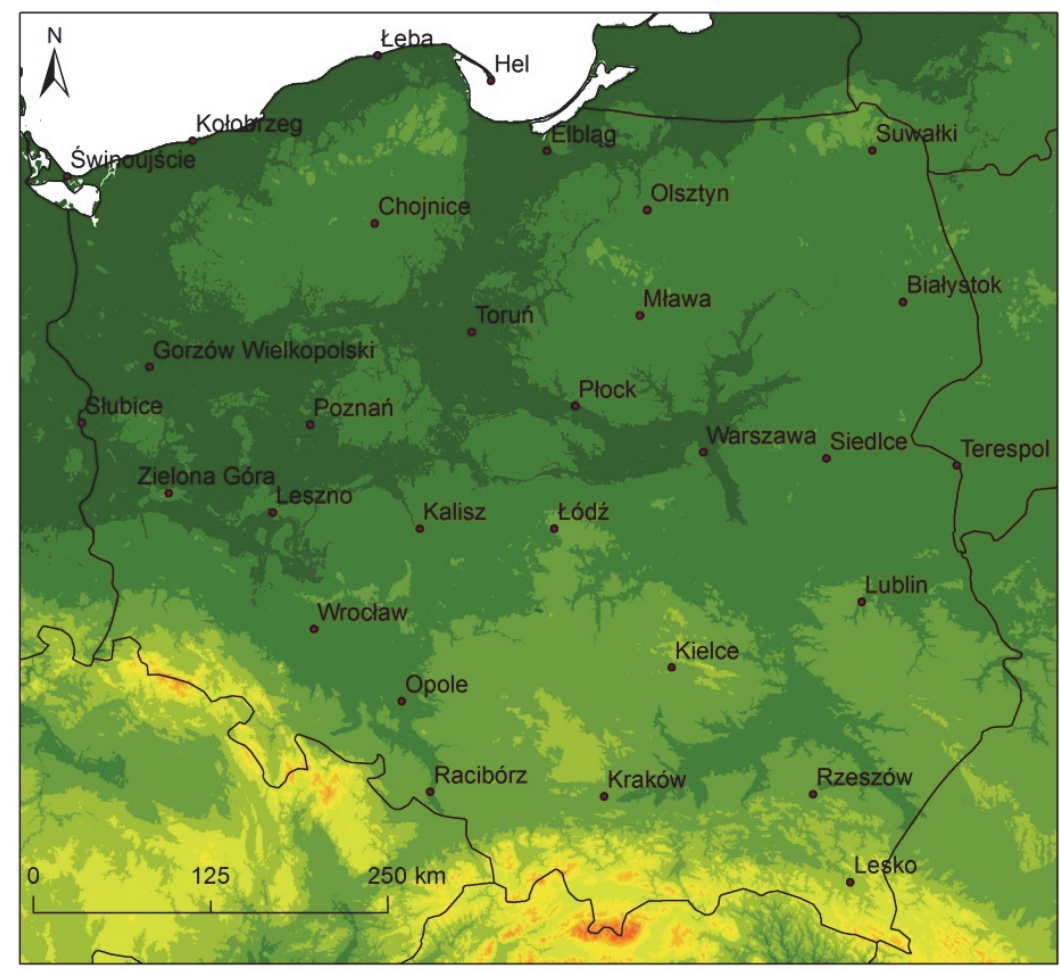

Fig. 1. Locations of meteorological stations.

First, the start and end dates of the growing season were determined, and the season itself was defined as the period with average daily air temperature $\geq 5{ }^{\circ} \mathrm{C}$. The above definition was previously accepted in numerous studies (Carter, 1998; Skaugen and Tveito, 2004; Linderholm, et al., 2008; Żmudzka, 2012; Radzka, 2013). The start and end dates of the aforementioned period were determined using the mathematical formulas proposed by Gumiński (1948).

This method is based on the following assumptions: the monthly average temperature falls on the 15th day of a month, each month has 30 days, and monthly temperature changes are evenly distributed. The formulas used:

$$
\begin{aligned}
& x=30[(t d-t 1) /(t 2-t 1)], \\
& x=30[(t 1-t d) /(t 1-t 2)],
\end{aligned}
$$

where $t d$ is the threshold temperature of the growing season $\left(5^{\circ} \mathrm{C}\right) ; t 1$ is the average temperature in the month preceding the threshold temperature; $t 2$ is the average temperature in the month following the threshold temperature; $x$ is the number of days between the day with the threshold temperature and the 15th day of the preceding month.

The number of days calculated on the basis of the aforesaid formulas is added to the 15th day of the month preceding the threshold temperature. If the 
sought number is greater than 15 , when adding, one should consider the actual number of days in a given month. The obtained date is the beginning of the separated period in time of the temperature increase and the end of the separated period in time of the decreasing temperature. The above-mentioned method is widely adopted in determining the growing and thermal seasons for both the multi-year period and individual years (Skowera and Kopeć, 2008; Szyga-Pluta, 2011; Kepińska-Kasprzak and Mager, 2015; Czernecki and Miętus 2017; Tomczyk and Szyga-Pluta, 2019). Kepińska-Kasprzak and Mager (2015) compared the thermal vegetation period determined by the method of Gumiński with those determined by the method of Huculak and Makowiec (the latter consists in calculating the accumulated series of deviations of average daily air temperature values from appropriate threshold values) for the period 1966-2005, and stated that in long-term datasets, both methods lead to similar results. The comparison of the results based on the phenological observations, and these obtained with the Gumiński method proved the compatibility of them (Situch et al., 2016).

Subsequently, changes in the beginning and end as well as the length of the growing season in the analyzed multi-year period were determined. To this end, the non-parametric Mann-Kendall test was used to detect the trend in the time series. The strength of the trends of characteristics in the multi-year period was determined by Sen's non-parametric method (Salmi et al., 2002).

In the next stage, the classification of the determined growing seasons was made based on the value of the standard deviation. On this basis, the following classes were established (Wegrzyn, 2008):

$$
\begin{aligned}
& \text { A - anomalously short: } \mathrm{GSL} \leq \mathrm{GSL}_{\mathrm{AV}}-2 \delta \\
& \mathrm{B} \text { - short: } \mathrm{GSL}_{\mathrm{AV}}-2 \delta<\mathrm{GSL} \leq \mathrm{GSL}_{\mathrm{AV}}-1 \delta ; \\
& \mathrm{C} \text { - normal (average): } \mathrm{GSL}_{\mathrm{AV}}-1 \delta<\mathrm{GSL}<\mathrm{GSL}_{\mathrm{AV}}+1 \delta \text {; } \\
& \text { D - long: GSL } \mathrm{AV}+1 \delta \leq \mathrm{GSL}<\mathrm{GSL}_{\mathrm{AV}}+2 \delta ; \\
& \text { E - anomalously long: } \mathrm{GSL} \geq \mathrm{GSL}_{\mathrm{AV}}+2 \delta,
\end{aligned}
$$

where GSL is the growing season length, $\mathrm{GSL}_{\mathrm{AV}}$ is the average growing season length, $\delta$ is the standard deviation.

The above classification was carried out for each station individually. Next, the frequency of occurrence of growing seasons in individual classes was determined.

\section{Results}

In the years 1966-2015 in Poland, the growing season started the earliest in the western and south-western regions, and the latest in the north-eastern regions. The average date of the beginning of the growing season was March 26, and it 
changed from March 18 in Słubice to April 7 in Suwałki (Fig. 2A). In most stations, the earliest beginning of the period occurred in 1990, while the latest in 1997, 1970, and 1980. Extreme dates of the beginning of the growing season fluctuated from January 29 (1990) in Słubice to May 5 (1970) in Kołobrzeg. The aforementioned data shows that the range of the variability of the beginning of the growing season was 97 days in the study area.

The growing season ended the earliest in the north-eastern regions and the latest in the northern and western regions. On average, the end of the period was recorded on November 7, although this date changed from October 25 in Suwałki to November 16 in Hel and Leba (Fig. 2B). In the majority of stations, the earliest end of the growing season was recorded in 1993, 1973, and 1998, while the latest in 2015, 2000, and 2006. Extreme dates of the end of the growing season ranged from October 8 (1977) in Terespol to January 19 (2007) in Stubice. It follows that the range of the variability in the ending time of the growing season was 104 days in the study area.

(a)

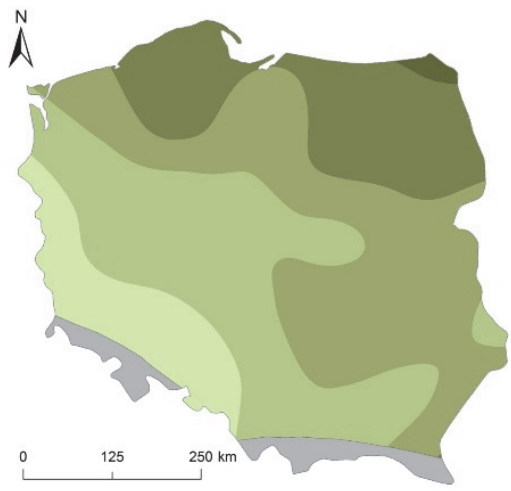



(b) $\Lambda^{N}$

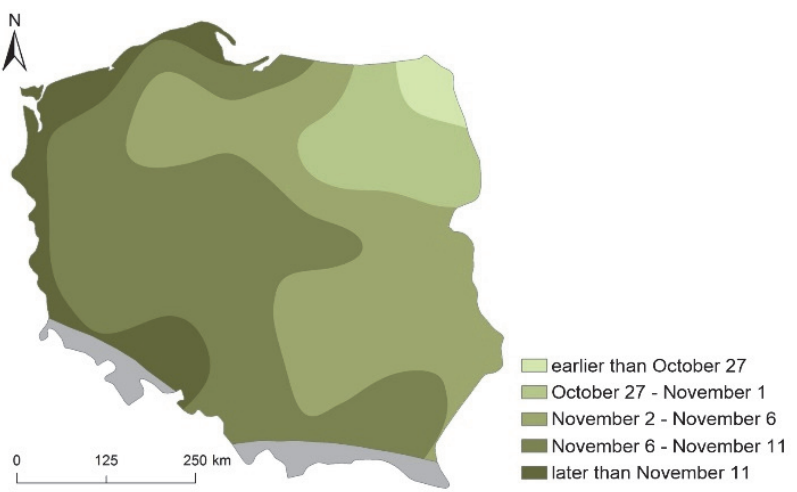

Fig. 2. Average growing season start date (A), end date (B) in Poland in the years 1966-2015.

In the analyzed multi-year period, the growing season started increasingly early. The strongest and statistically significant changes were recorded in northern and north-eastern Poland. In Łeba and Kołobrzeg, the rate of these changes was -4.2 days/10 years and -4.1 days/10 years, respectively (Figs. $3 \mathrm{~A}$ and 4). On the other hand, the end of the growing season was increasingly late. Statistically significant changes were found on the east coast, in central and southern Poland, and the most intensive changes occurred in $\mathrm{Hel}$ (2.6 days/10 years) and Wrocław (2.5 days/10 years) (Figs. 3B and 4). 
(A)

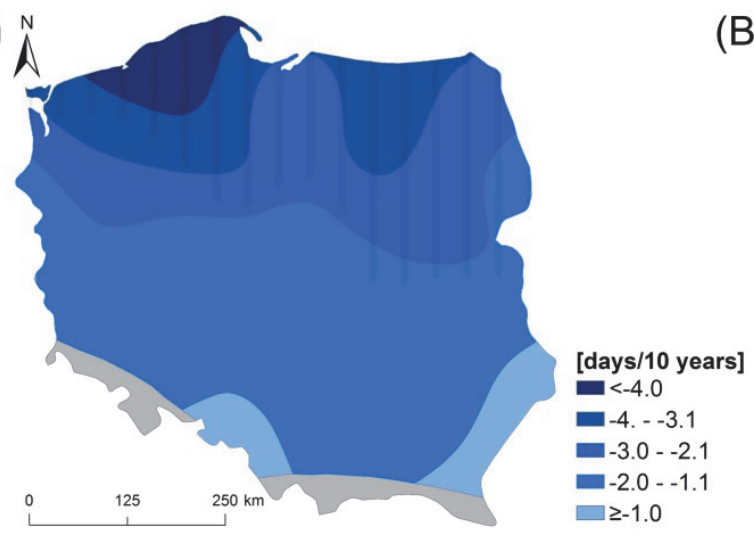

(B)

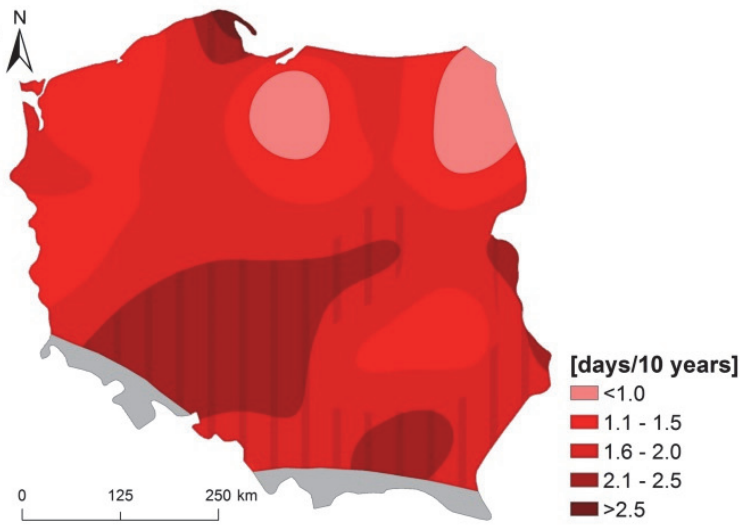

Fig. 3. Changes in the beginning (A) and end (B) dates of the growing season in Poland in years 1966-2015 (vertical lines indicate statistically significant changes).
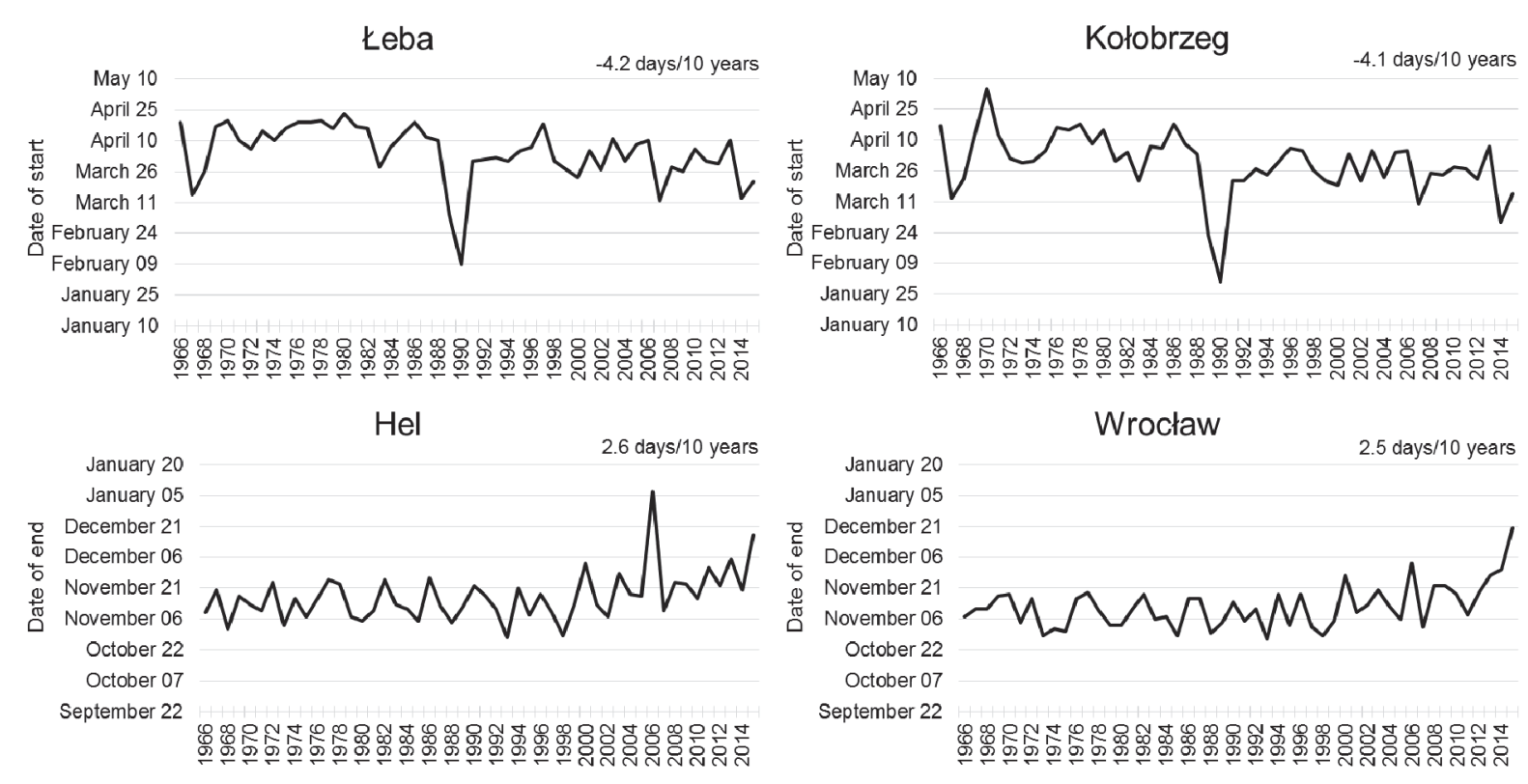

Fig. 4. Changes in the beginning and end dates of the growing season in selected stations in the years 1966-2015.

The average length of the growing season was 227 days in Poland. The increase in the growing season length took place from the northeast to the southwest. In Suwałki, the average length of the period was 202 days, while in Stubice, 242 days (Fig. 5A). The variability of length in the majority of the 
country was similar, as evidenced by the values of standard deviation, which, apart from seaside stations, fluctuated at a similar level, 13-15 days. In the considered multi-year period, the shortest growing season lasted 179 days in 1992 (Suwałki), while the longest lasted 297 days in 2006 (Stubice). The conducted research showed an increase in the length of the growing season, which was statistically significant, except for two stations in the southern part of the country (Fig. 5B). The largest increase in the length of the growing season was recorded in northern Poland, in particular in seaside stations, i.e., in Łeba (6.9 days/10 years) and Hel (6.8 days/10 years).

(A)

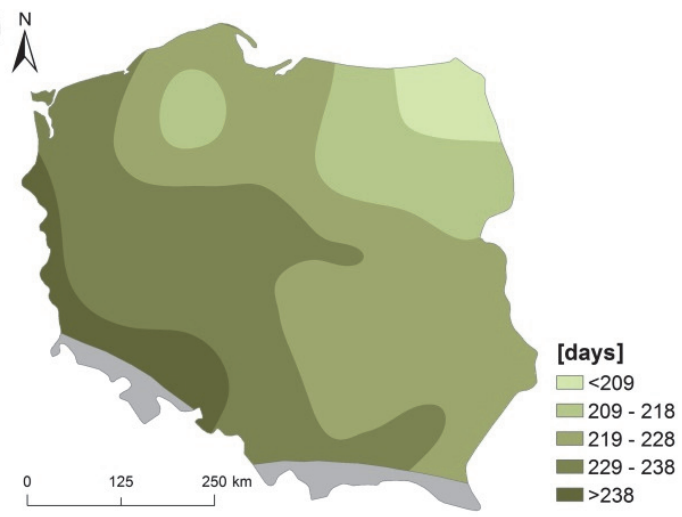

(B)

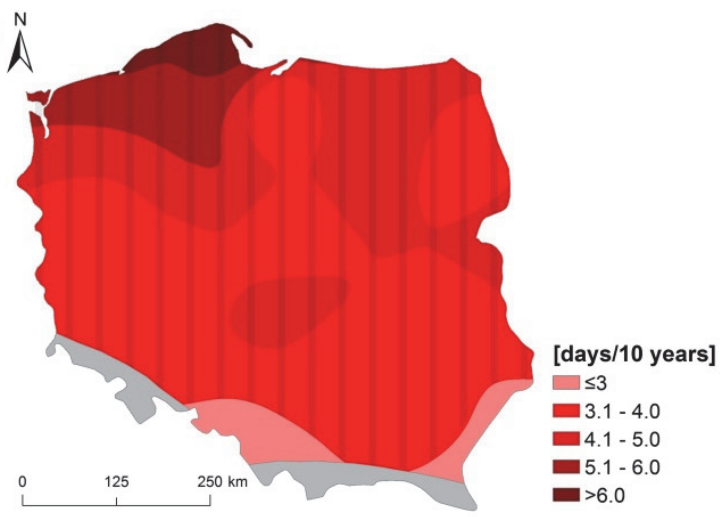

Fig. 5. Average length of the growing season (A) and its changes (B) in Poland in the years 1966-2015 (vertical lines indicate statistically significant changes).

As already indicated above, in the majority of stations (in 56\% of stations) the shortest growing season occurred in 1997, and according to the accepted classification, in 9 stations it was classified as anomalously short and in 17 as short. Its length varied from 180 days in Mława to 227 days in Świnoujście. The period in each station was shorter than the average by 9 days in Świnoujście to 35 days in Łódź and Mława. The largest deviations were recorded mainly in the central and southeastern parts of Poland ( $>30$ days). The shortening of the growing season was due to its later start time (except for Świnoujście) and a faster ending (Fig. 6). The beginning of the period was recorded from March 23 in Świnoujście to April 21 in Lesko. The average delay was approximately 14 days, while in individual stations it ranged from 4 days in Gorzów Wielkopolski to 23 days in Lesko. The largest deviations were recorded primarily in the central and south-eastern regions. In turn, the end of the period ranged from October 13 in Mława to November 9 in Hel. On average, it 
occurred earlier by 10 days in the research area. In individual stations, the advance of the ending changed from 5 days in Kraków to 18 days in Mława. The largest deviations were noted above all in central Poland.

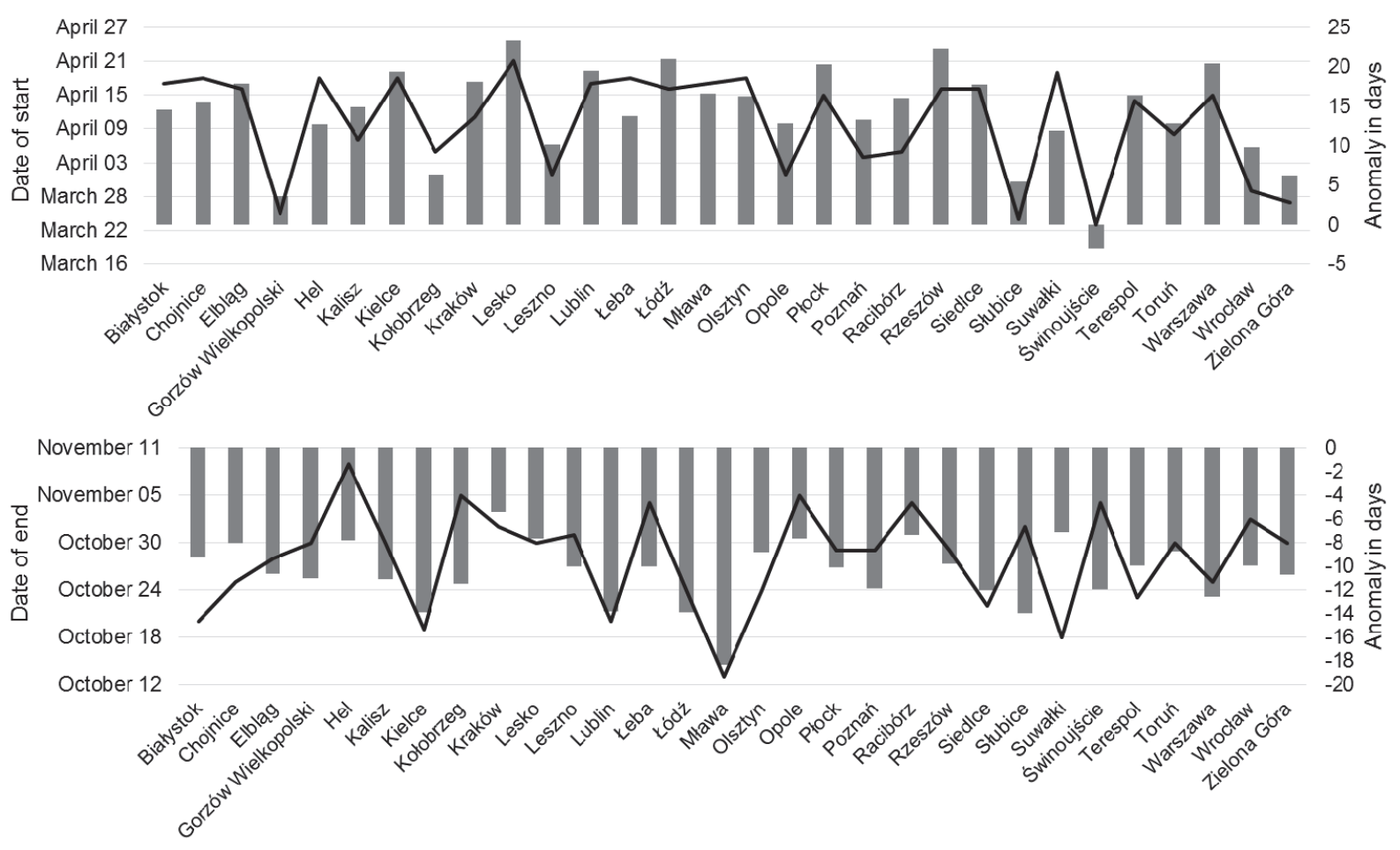

Fig. 6. The beginning and end dates of the growing season in the year 1997 (line) and the deviation from the multi-year average of its length (columns) in Poland.

In turn, in $63 \%$ of stations, the longest growing season occurred in 1990 and, according to the adopted classification, in 27 stations it was classified as anomalously long and in 3 as long. This period lasted from 229 days in Suwałki to 295 days in Kołobrzeg. In the entire research area, the period was longer than the average for the multi-year period from 27 days in Kielce and Suwałki to 62 days in Kołobrzeg. The largest deviations were recorded in the northern and western parts of Poland. The prolongation of the growing season was caused by its earlier start and later ending (except for Świnoujście), although the change of the beginning date was decisive (Fig. 7). On average, this period began 35 days earlier, and in individual stations these deviations ranged from 3 days in Świnoujście to 58 days in Kołobrzeg. In turn, the end of the period ranged from November 1 in Suwałki to November 22 in Hel. The delay of the end of the 
growing season was relatively short and amounted to a maximum of 10 days in Kraków. The largest deviations were recorded mainly in the southern and eastern parts of Poland.

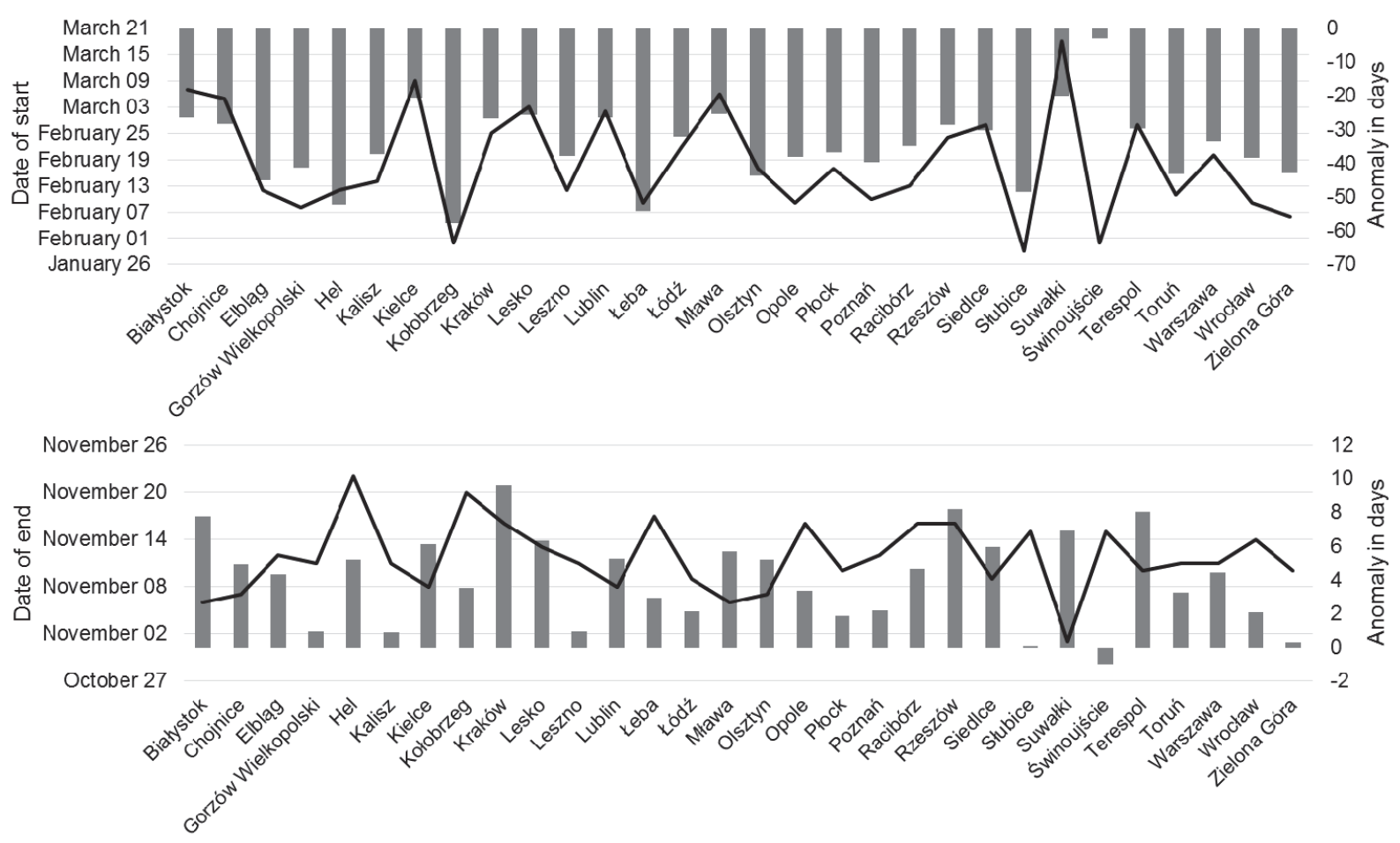

Fig. 7. The beginning and end dates of the growing season in the year 1990 (line) and the deviation from the multi-year average of its length (columns) in Poland.

In Poland in the years 1966-2015, the normal growing season $(\mathrm{C}$ in Table 1) lasted on average from 213 to 241 days (Table 1). The length of the normal growing season varied from 188-216 days in Suwałki to 223-279 days in Stubice. The short period (B) lasted on average 199-213 days, and the season lasting less than 199 days was considered to be anomalously short (A) for Poland. The anomalously short growing season lasted less than 174 days, while in Opole the length of anomalously short growing season was below 208 days. The duration of the long growing season (D) in Poland was on average 241255 days, and it varied from 216-230 days in Suwałki to 260-279 days in Stubice. The anomalously long growing season (E) in Poland lasted on average over 255 days, changing from $>230$ days in Suwałki to $>279$ days in Słubice. 
Table 1 The growing season duration classes in Poland with examples of the shortest and longest seasons in days, in the years 1966-2015

\begin{tabular}{|c|c|c|c|c|c|c|}
\hline & \multirow{2}{*}{ Growing season } & \multirow{2}{*}{ Poland } & \multicolumn{2}{|c|}{ The shortest } & \multicolumn{2}{|c|}{ The longest } \\
\hline & & & Suwałki & Mlawa & Opole & Słubice \\
\hline A & anomalously short & $<199$ & $<174$ & $<188$ & $<208$ & $<204$ \\
\hline B & short & 199-213 & $174-188$ & $188-201$ & $208-223$ & $204-223$ \\
\hline $\mathrm{C}$ & normal & $213-241$ & $188-216$ & $201-229$ & $223-254$ & $223-260$ \\
\hline $\mathrm{D}$ & long & $241-255$ & $216-230$ & $229-242$ & $254-270$ & $260-279$ \\
\hline $\mathrm{E}$ & anomalously long & $>255$ & $>230$ & $>242$ & $>270$ & $>279$ \\
\hline
\end{tabular}

The classification of the growing season length for the area of Poland showed that in the analyzed years, the normal length of the growing season was dominant (Table 2). On average in Poland, normal seasons constituted $70 \%$ of all seasons, from $64 \%$ in Suwałki to $78 \%$ in Kołobrzeg, Zielona Góra, and Stubice, which corresponds to the number of years from 32 to 39. Both short and long seasons occurred with similar frequency (15\% each). Anomalously short seasons appeared sporadically. In the first part of the analyzed period, the occurrence of short seasons was observed, i.e., in 1971, 1973, 1979, 1980, 1985, 1988, 1993, and 1997. However, there were no long seasons. In Poland, long seasons occurred four times: in 1989, 2000, 2006, and 2012. On the other hand, anomalously long growing seasons occurred in 1990, 2014, and 2015.

Table 2. Classification of the growing season length in the years 1966-2015 in Poland

\begin{tabular}{clllllllll}
\hline \hline Year & GPL & Year & GPL & Year & GPL & Year & GPL & Year & GPL \\
\hline \hline 1966 & 221 & 1976 & 214 & 1986 & 228 & 1996 & 225 & 2006 & 247 \\
1967 & 240 & 1977 & 236 & 1987 & 216 & 1997 & 202 & 2007 & 235 \\
1968 & 229 & 1978 & 225 & 1988 & 208 & 1998 & 214 & 2008 & 238 \\
1969 & 221 & 1979 & 207 & 1989 & 241 & 1999 & 229 & 2009 & 238 \\
1970 & 216 & 1980 & 205 & 1990 & 267 & 2000 & 249 & 2010 & 230 \\
1971 & 212 & 1981 & 223 & 1991 & 230 & 2001 & 223 & 2011 & 227 \\
1972 & 225 & 1982 & 226 & 1992 & 218 & 2002 & 235 & 2012 & 243 \\
1973 & 210 & 1983 & 227 & 1993 & 212 & 2003 & 226 & 2013 & 228 \\
1974 & 226 & 1984 & 219 & 1994 & 230 & 2004 & 230 & 2014 & 258 \\
1975 & 217 & 1985 & 212 & 1995 & 218 & 2005 & 220 & 2015 & 259 \\
\hline
\end{tabular}

GPL - growing period length (in days) 
The growing season length varied in individual stations (Figs. 8 and 9). Anomalously short periods occurred in stations located in the southeastern and central parts of Poland, and in the remaining area, they did not occur at all. The area in the belt extending from the south, through central Poland to the northeast is characterized by a higher frequency of growing seasons that are shorter than the average. Most often, short seasons were observed in Suwałki, Białystok, Olsztyn, and Racibórz (18\%), while the least often in Słubice (8\%) and Elbląg (10\%). Long growing seasons occurred more often than on average in the eastern regions, and most often in Suwałki and Lublin (16\%). The northwestern region of the country was characterized by the smallest frequency of these seasons. In Zielona Góra and Kołobrzeg it was only 4\%, and in Hel and Słubice $6 \%$. In Western Poland, anomalously long seasons were the most frequent (Stubice 8\%). Their lowest frequency was observed in the northeastern and central-eastern parts of the country $(2 \%)$.



Fig. 8. Frequency (\%) of occurrence of particular classes of the growing season length in Poland (1966-2015).

Analysis of the growing season length in individual stations showed that periods longer than the average occurred in several stations in 1967, 1977, and 1989. However, exceptionally long seasons did not occur in any of the stations until 1990 (Fig. 9) it was mentioned earlier, in most of the country the growing season of 1990 was classified as anomalously long. In the last 20 years of the analyzed period in individual stations, there were anomalously long seasons. On the other hand, in 2014 and 2015, these seasons occurred in most of Poland. 
Short seasons were more frequent than on average in many stations in 1979, $1980,1988,1993$, and in 1997, which was also the year with the highest number of stations with an anomalously short season.
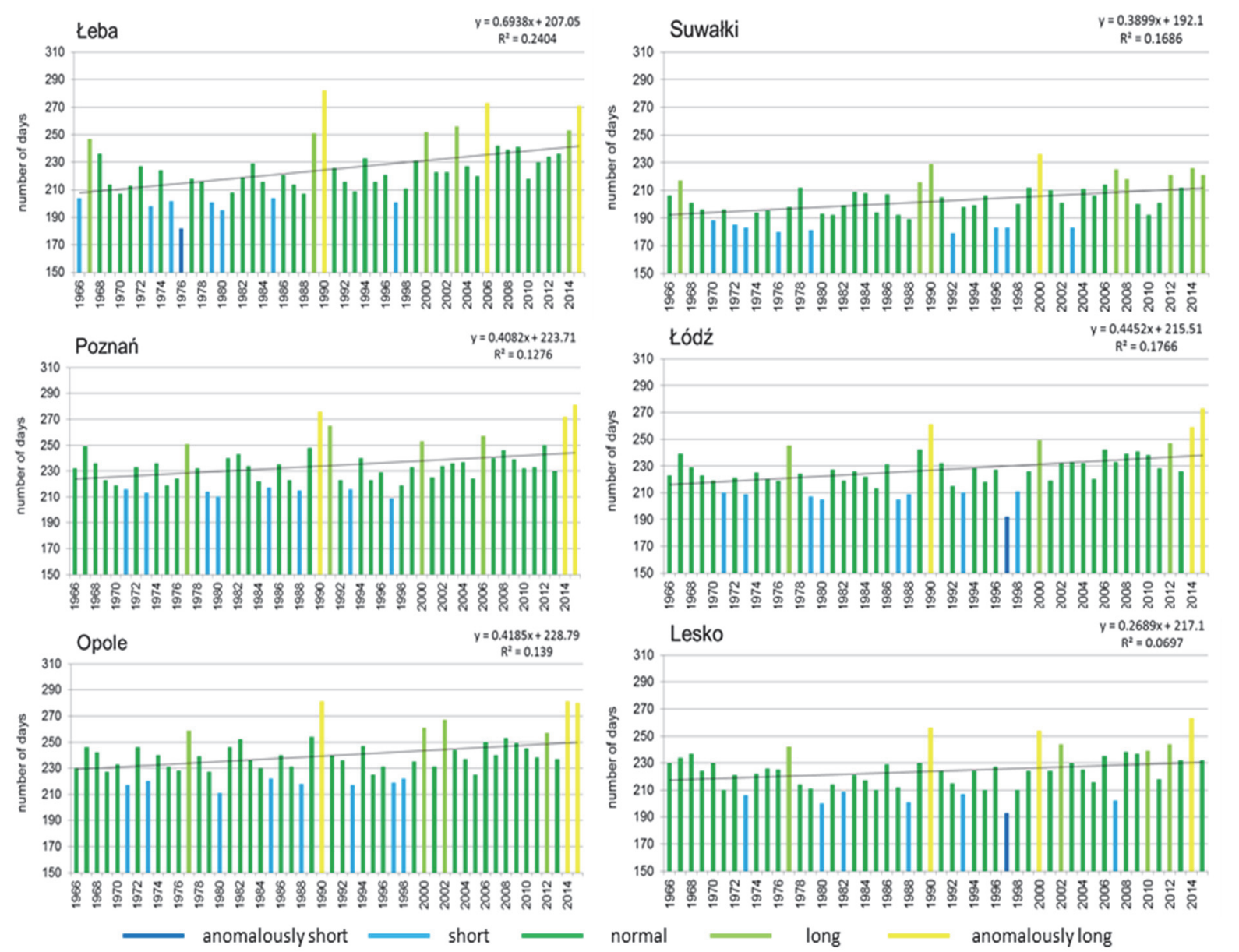

Fig. 9. Classification of the growing season length in selected stations in Poland (19662015) along with the trend line.

The occurrence of seasons belonging to particular length classes is reflected in deviations from the average of the growing season length in the years 1966-2015 (Fig. 10). Negative deviations were observed more often at the beginning of the analyzed period, especially in stations located in the northern and eastern parts of Poland. For stations in Western Poland, greater variations in deviations from the average are characteristic. The highest negative deviation occurred in Leba in 1976 ( -43 days), and the largest positive deviation occurred in Kołobrzeg in 1990 (+62 days). In the last 10 years, the domination of positive 
deviations in the growing season length has been clearly visible in most stations, with particularly high values in the western part of the country. The last two seasons, during which deviations in many stations exceeded 40 days, were especially distinguishing.
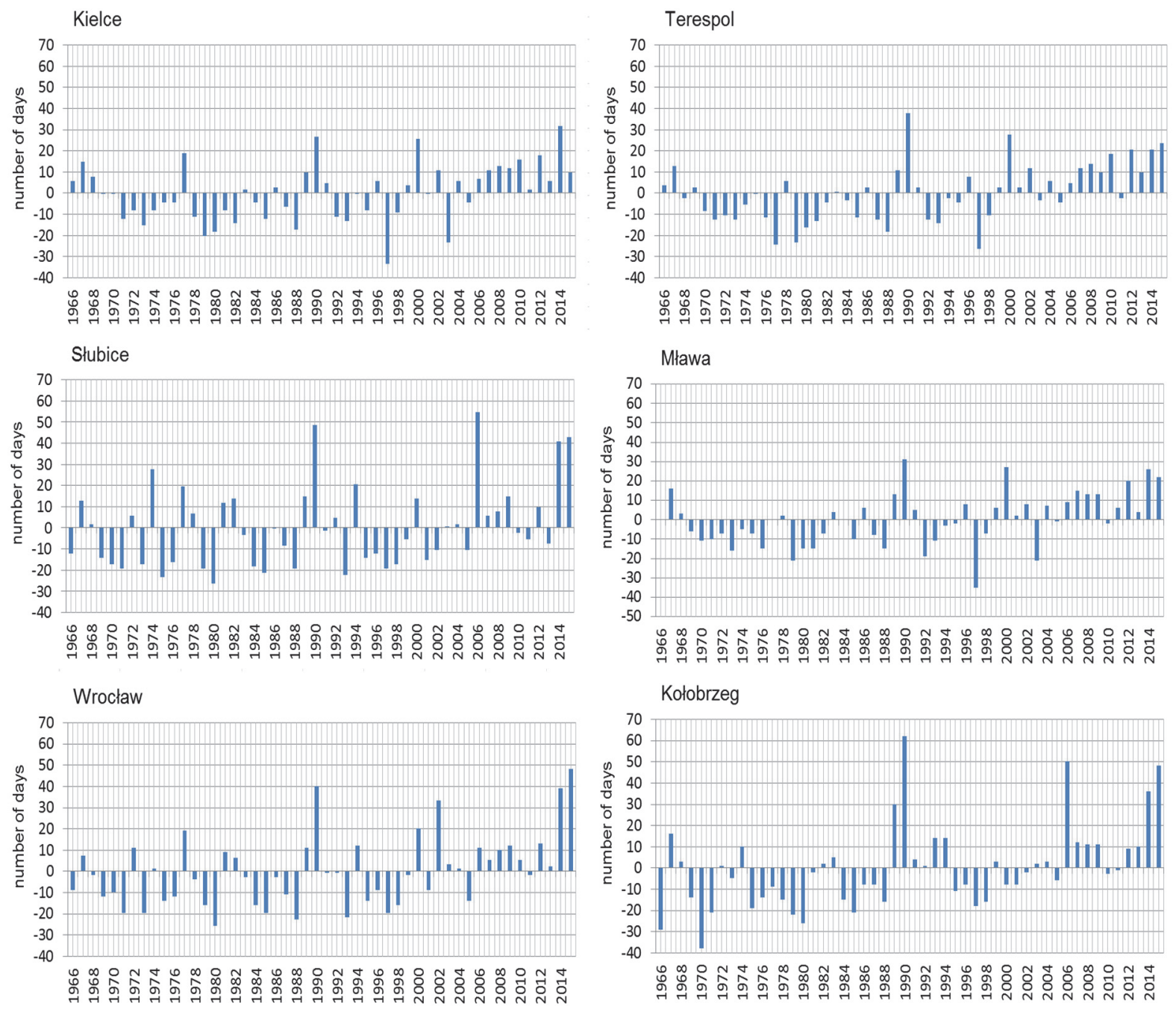

Fig. 10. Deviations from the average growing season length in selected stations in Poland (1966-2015). 


\section{Discussion and summary}

In the years 1966-2015 in Poland, the growing season started the earliest in the western and southwestern regions, and the latest in the northeastern regions. By contrast, the end of the growing season followed the opposite, i.e., it was the earliest in the northeastern regions, and the latest in the northern and western regions. In the analyzed period, the growing season started increasingly early and ended increasingly late. The greatest advance of the beginning was recorded on the coast - in Łeba and Kołobrzeg. The rate of these changes was -4.2 days $/ 10$ years and -4.1 days/ 10 years, respectively. In turn, the delay of the end of the growing season was the greatest in Hel (2.6 days/10 years) and Wrocław ( 2.5 days/10 years). The start and end dates' shifting contributed to the extension of the growing season in Poland in the analyzed period. The largest increase in the growing season length was recorded in the northern part of Poland, in particular in seaside stations, i.e., in Łeba (6.9 days/10 years) and Hel (6.8 days/10 years), which is in line with the results obtained for the Baltic region, where the duration of this season increased by approximately 7 days in the second half of the twentieth century (Linderholm et al., 2008). The increase in the length of the growing season in Poland in 1966-2015 was mainly due to its earlier beginning, which was confirmed by the results obtained for Poland by Olszewski and Żmudzka (1997), as well as Bochenek et al. (2013) for the southeastern area of Poland in 2001-2011. According to Nieróbca et al. (2013), the increasingly late ending of the meteorological growing season was the reason for extending its duration in 2001-2009 in relation to 1971-2000. On the other hand, Kruzel et al. (2015) stated that the average four-day increase in the duration of this period in Poland between 1981 and 2010 is the result of both its starting two days earlier and ending two days later. Research conducted by Wegrzyn (2008) showed that in the southeastern region of Poland in 1991-2006, the average duration of the growing season did not get longer; however, the range of its variability increased significantly. The increase in the length of the growing season in different regions of Poland was also confirmed by other authors, among others, Skowera and Kopeć (2008), Żmudzka and Dobrowolska (2001), Olechnowicz-Bobrowska and Wojkowski (2006), Tylkowski (2015), Graczyk and Kundzewicz (2016). A similar trend was observed in other regions of Europe (Carter, 1998; Menzel et al., 2003; Jaguus, 2006; Linderholm et al., 2008; Irannezhad and Kløve, 2015; Potopova et al., 2015) and in China (Dong et al., 2013). The increase in the length of the growing season in Europe by 10.8 days from the 1960s was found by Menzel and Fabian (1999) on the basis of 30-year-long observations, which has been confirmed by later phenological observations (Menzel, 2000; Stenseth et al., 2002). Christidis et al. (2007) proved that now the increase in the length of the growing season is mainly due to its earlier beginning, however, in the future both shifting the start and end 
dates will contribute to extending its duration. According to Song et al. (2010), these changes are occurring faster and faster.

The cause of vegetation lengthening was spatially diverse in Poland. This variation was also present in Finland: in the north it was the ending delay, and the earlier beginning in the center. On the other hand, on the southwest coast of Finland, both the start and the end of the growing season were equally shifted (Irannezhad and Kløve, 2015). Song et al. (2010) showed that the growing season was prolonged mainly due to an earlier beginning by 1.7 days/10 years in northern China, and in the southern part, the reason was an even shifting of the start and end dates. In northern and central Europe, more significant changes occurring in spring were observed on the basis of phenological phases (Menzel, 2000).

The growing season in Poland in the analyzed period lasted on average 227 days. The increase in the growing season length took place from the northeast to the southwest. In Suwałki, the average length of the period was 202 days, while in Słubice, 242 days. There are also specific significant fluctuations in the length of the growing season year by year. The shortest period in Poland lasted, on average, 267 days in 1990, and the longest period with 202 days occurred in 1997. For reference, in Finland the average duration of the growing season was 116 days in the years 1961-2011, fluctuating from 98 days in 1977 to 146 days in 2011 (Irannezhad and Kløve, 2015).

The classification of the growing season length for the area of Poland showed that in the analyzed years, the normal length of the growing season was dominant (70\%). Short periods occurred with a frequency of $14 \%$, and for long periods it was $10 \%$. Periods of anomalous length in Poland are rare: anomalously long periods occurred with a frequency $5 \%$, and for anomalously short periods it was $1 \%$. Anomalously short periods occurred in stations located in the southeastern and central parts of Poland, and in the remaining area, they did not occur at all. In Western Poland, anomalously long seasons were the most frequent. Their lowest frequency was observed in the northeastern and centraleastern parts. In the years 1951-1990 in the southeastern part of Poland, normal growing seasons occurred by $71.7 \%$, long periods by $11.1 \%$, and short periods by $11.4 \%$, according to Wegrzyn (2008). Sporadically there were anomalously long and anomalously short seasons. However, the higher frequency of anomalously short periods (3.3\%) and the lower frequency of anomalously long ones $(2.5 \%)$ clearly marked in this area, which confirms the results obtained in this study. It can be noticed, that there is a tendency of smaller and smaller frequency of short and anomalously short seasons, and more and more often occurring of long and anomalously long seasons in Poland in the analyzed period. Also, Bartoszek and Banasiewicz (2007) stated that the tendency of the occurrence of warmer than normal growing seasons, which was clearly visible in Central Europe in the decade of 1991-2000, persists. 


\section{Conclusions}

In summary, it should be noted that in the years 1966-2015 in Poland:

- Statistically significant changes of the growing season length were found on the east coast, in the central and southern parts of Poland, and the most intensive changes occurred in Hel (2.6 days/10 years) and Wrocław (2.5 days/10 years);

- Anomalously short growing seasons occurred sporadically and covered the largest area of Poland in 1997;

- Short growing seasons were more frequent in the first three decades of the analyzed multi-year period;

- Long growing seasons were characterized by higher frequency in the second half of the surveyed period;

- Anomalously long growing seasons occurred sporadically before 1990 and only in individual stations;

- Anomalously short growing seasons occurred only in the middle eastern part of Poland, while anomalously long ones covered most of the country.

\section{References}

Bochenek, W., Dedo, J., and Marczewski, W., 2013: Zróżnicowanie długości i warunków termicznych okresu wegetacyjnego na obszarze Beskidów i Pogórzy w latach 2001-2011 na podstawie danych zgromadzonych w bazie GLDAS. [Differentiation of duration and thermal conditions of the vegetation season in the Beskid Mts. and Carpathian Foothill in years 2001-2011 on the GLDAS database]. Monitoring Środowiska Przyrodniczego 14, 79-85. (In Polish).

Carter, T.R., 1998: Changes in the thermal growing season in Nordic countries during the past century and prospects for the future. Agric. Food Sci.7, 161-179. https://doi.org/10.23986/afsci.72857

Chmielewski, F.M., Muller, A., and Bruns, E., 2004: Climate changes and trends in phenology of fruit trees and field crops in Germany, 1961-2000. Agric. Forest Meteorol. 121, 69-78. https://doi.org/10.1016/S0168-1923(03)00161-8

Chmielewski, F.M. and Rötzer, T., 2001: Response of tree phenology to climate change across Europe. Agric. Forest Meteorol. 108, 101-112. https://doi.org/10.1016/S0168-1923(01)00233-7

Christidis, N., Stott, P.A., and Brown, S., 2007: Human contribution to the lengthening of the growing season during 1950-99. J. Climate 20, 5441-5454. https://doi.org/10.1175/2007JCLI1568.1

Czernecki, B. and Miętus, M., 2017: The thermal seasons variability in Poland, 1951-2010. Theor. Appl. Climatol. 127, 481-493. https://doi.org/10.1007/s00704-015-1647-z

Dong, M.Y., Jiang, Y., Zhang, D.Y., and Wu, Z.F., 2013: Spatiotemporal change in the climatic growing season in Northeast China during 1960-2009. Theor. Appl. Climatol. 111, 693-701. https://doi.org/10.1007/s00704-012-0706-y

Graczyk, D. and Kundzewicz, Z.W., 2016: Changes of temperature-related agroclimatic indices in Poland. Theor. Appl. Climatol. 124, 401-410. https://doi.org/10.1007/s00704-015-1429-7

Gumiński. R., 1948: Próba wydzielenia dzielnic rolniczo-klimatycznych w Polsce. [Attempt to separate agricultural and climatic districts in Poland]. Przeglad Meteorologiczno-Hydrologiczny 1, 7-20. (In Polish). 
IPCC, 2013: Climate change: The physical science basis. Contribution of Working Group I to the Fifth Assessment Report of the Intergovernmental Panel in Climate Change, Cambridge University Press, Cambridge, pp. 33.

Irannezhad, M. and Kløve, B., 2015: Do atmospheric teleconnection patterns explain variations and trends in thermal growing season parameters in Finland? Int. J. Climatol. 35, 4619-4630. https://doi.org/10.1002/joc.4311

Jaguus, J., 2006: Climatic changes in Estonia during the second half of the 20th century in relationship with changes in large-scale atmospheric circulation. Theor. Appl. Climatol. 83, 77-88. https://doi.org/10.1007/s00704-005-0161-0

Kepińska-Kasprzak, M. and Mager, P., 2015: Thermal growing season in Poland calculated by two different methods, Annals of Warsaw University of Life Sciences-SGGW Land Reclamation 47, 261-273. https://doi.org/10.1515/sggw-2015-0030

Krużel, J., Ziernicka-Wojtaszek, A., Borek, L., and Ostrowski, K., 2015: Zmiany czasu trwania meteorologicznego okresu wegetacyjnego w Polsce w latach 1971-2000 oraz 1981-2010. [The changes in the duration of the meteorological vegetation period in Poland in the years 19712000 and 1981-2010]. Inżynieria Ekologiczna 44, 47-52. (In Polish). https://doi.org/10.12912/23920629/60024

Linderholm, H.W., 2006: Growing season changes in the last century. Agric. Forest Meteorol. 137, 1-14. https://doi.org/10.1016/j.agrformet.2006.03.006

Linderholm, H.W., Walther, A., and Chen, D., 2008: Twentieth-century trends in the thermal growing season in the Greater Baltic Area. Climatic Change 87, 405-419. https://doi.org/10.1007/s10584-007-9327-3

Menzel, A. and Fabian, P., 1999: Growing season extended in Europe. Nature, 397, 659. https://doi.org/10.1038/17709

Menzel, A., 2000: Trends in phenological phases in Europe between 1951 and 1996. International J.Biometeorol. 44, 76-81. https://doi.org/10.1007/s004840000054

Menzel, A., 2003: Plant phenological anomalies in Germany and their relation to air temperature and NAO. Climatic Change 57, 243-263. https://doi.org/10.1023/A:1022880418362

Menzel, A., Jakobi, G., Ahas, R., Scheifinger, H., and Estrella, N., 2003: Variations of the climatological growing season (1951-2000) in Germany compared with other countries. Int. J. Climatol. 23, 793-812.

Miętus, M., 2005: Ekstremalne zjawiska klimatyczne z perspektywy IPPC. [Extreme climate phenomena from the IPPC perspective]. In: (eds. Bogdanowicz, E., Kossowska-Cezak, U., Szkutnicki, J.,) Ekstremalne zjawiska hydrologiczne i meteorologiczne. [Extreme hydrological and meteorological phenomena]. PTG, IMGW, Warszawa, 19-31. (In Polish)

Nieróbca, A., 2009: Skutki zmian klimatycznych dla rolnictwa w Polsce - ocena zagrożeń. [The effects of climate change on agriculture in Poland - risk assessment]. In: (eds. Kozyra, J., Nieróbca, A., Mizak, K.) Zmiany klimatyczne a rolnictwo w Polsce - ocena zagrożeń i sposoby adaptacji. [Climate change and agriculture in Poland - risk assessment and methods of adaptation]. IUNGPIB, Puławy. (In Polish).

Nieróbca, A., Kozyra, J., Mizak, K., Wróblewska, E., 2013: Zmiana długości okresu wegetacyjnego w Polsce. [Changing length of the growing season in Poland]. Woda-Środowisko-Obszary Wiejskie, 13, 2 (42), 81-94. (In Polish).

NOAA (2018) https://www.ncdc.noaa.gov/sotc/global/201713

Olechnowicz-Bobrowska, B., and Wojkowski, J., 2006: Okresy termiczne w południowej części Wyżyny Krakowsko-Częstochowskiej (1991-2000). [Thermal periods in the southern part of the Cracow-Częstochowa Upland (1971-2000)]. In: (eds. Trepińska, J., Olecki, Z.) Klimatyczne aspekty środowiska geograficznego [Climatic aspects of the geographical environment]. Instytut Geografii i Gospodarki Przestrzennej UJ, Kraków, 51-61.

Olszewski, K. and Żmudzka, E. 1997: Zmiany okresu wegetacyjnego w Polsce. [Changes of length of the vegetative period in Poland]. Prace i Studia Geograficzne 20,93-103. (In Polish).

Piniewski, M., Mezghani, A., Szcześniak, M., and Kundzewicz, Z., 2017: Regional projections of temperature and precipitation changes: Robustness and uncertainty aspects. Meteorol. Zeitschrift 26, 223-234. https://doi.org/10.1127/metz/2017/0813 
Potopova, V., Zahradnicek, P., Turkott, L., Stepanek, P., Soukup, J., 2015: The effects of climate change on variability of the growing seasons in the Elbe River Lowland, Czech Republic. $A d v$. Meteorol. Article ID 546920. https://doi.org/10.1155/2015/546920

Radzka, E., 2013: Okresy termiczne w środkowo-wschodniej Polsce (1971-2005). [Thermal periods in central-eastern Poland (1971-2005)]. Acta Agrophysica 20, 679-691. (In Polish).

Rahmstorf, S., Foster G., and Cahill N., 2017: Global temperature evolution: recent trends and some pitfalls. Environ. Res. Lett. 12, 054001. https://doi.org/10.1088/1748-9326/aa6825

Salmi, T., Maiittii, A., Anttila, P., Ruoho-Airola, T., and Amnel, T., 2002: Detecting Trends of Annual Values of Atmospheric Pollutants by the Mann-Kendall Test and Sen's Slope Estimates-The Excel Template Application MAKESENS. Publications on Air Quality No. 31; Finnish Meteorological Institute: Helsinki, Finland, 1-35.

Siluch, M., Dąbrowska, A., and Bartoszek, K., 2016: Początek okresu wegetacyjnego określany na podstawie danych meteorologicznych, teledetekcyjnych i pojawów fenologicznych leszczyny pospolitej. [The onset of growing season based on meteorological and remotely sensed data as well as phenological observations of the common haze]. Acta Scientarum Polonarum Formatio Circumientus 15(2), 117-125. (In Polish). https://doi.org/10.15576/ASP.FC.2016.2.117

Skaugen, T.E. and Tveito, O.E., 2004: Growing season and degree-day scenario in Norway for 20212050. Climate Res. 26, 221-232. https://doi.org/10.3354/cr026221

Skowera, B., and Kopeć, B., 2008: Okresy termiczne w Polsce południowo-wschodniej (1971-2000). [Thermal periods in south-eastern part of Poland (1971-2000)]. Acta Agrophysica 12(2), $517-$ 526. (In Polish).

Song, Y., Linderholm, H.W., Chen, D., and Walther, A., 2010: Trends of the thermal growing season in China, 1951-2007. Int. J. Climatol. 30, 33-43. https://doi.org/10.1002/joc.1868

Stenseth, N.C., Mysterud, A., Ottersen, G., Hurrel, J.W., Chan, K.S., and Lima, M., 2002: Ecological effects of climate fluctuations. Science 297, 1292-1296. https://doi.org/10.1126/science.1071281

Szyga-Pluta, K., 2011: Termiczne pory roku w Poznaniu w latach 2001-2008. [Thermal seasons in Poznań in the period 2001-2008]. Przeglad Geograficzny 83(1), 109-119. (In Polish). https://doi.org/10.7163/PrzG.2011.1.6

Tomczyk, A.M., Bednorz, E., 2016: Heat waves in Central Europe and their circulation conditions. Int. J. Climatol. 36, 770-782. https://doi.org/10.1002/joc.4381

Tomczyk, A.M. and Szyga-Pluta, K., 2019: Variability of thermal and precipitation conditions in the growing season in Poland in the years1966-2015. Theor. Appl. Climatol. 135, 1517-1530. https://doi.org/10.1007/s00704-018-2450-4

Tylkowski, J., 2015: The variability of climatic vegetative seasons and thermal resources at the Polish Baltic Sea coastline in the context of potential composition of coastal forest communities. Baltic Forestry 21, 73-82.

Węrzyn, A., 2008: Typowe i anomalne długości okresu wegetacyjnego na Lubelszczyźnie. [Typical and abnormal duration of vegetation season in the Lublin region]. Acta Agrophysica 12(2), 561573. (In Polish).

Wibig, J., 2018: Heat waves in Poland in the period 1951-2015: trends, patterns and driving factors. Meteorol. Hydrol. Water Manage. 6, 37-45. https://doi.org/10.26491/mhwm/78420

Żmudzka, E., 2012: Wieloletnie zmiany zasobów termicznych w okresie wegetacyjnym i aktywnego wzrostu roślin w Polsce. [Long-term changes of thermal resources in the vegetative period and the active growth of plants in Poland]. Woda-Środowisko-Obszary Wiejskie 12, 2 (38), 377-389. (In Polish).

Żmudzka, E. and Dobrowolska, M., 2001: Termiczny okres wegetacyjny w Polsce - zróżnicowanie przestrzenne i zmienność czasowa. [Thermal vegetation in Poland - spatial and temporal variability]. Przegląd Naukowy Wydziatu Inżynierii i Ksztattowania Środowiska SGGW 21, 7580. (In Polish). 